\title{
A Validated LC Method for the Quantitation of Cefotaxime in pH-Sensitive Nanoparticles
}

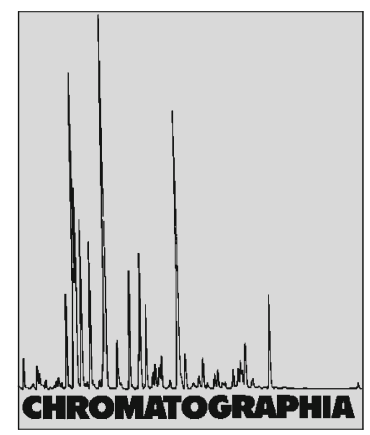

2010, 71, 373-381

\author{
Rosa Pereira ${ }^{1}$, Tommy Julianto ${ }^{1}$, Peh-Kim Ang $^{2}$, Sharon Sheue-Nee Ling ${ }^{3}$, Carlos Mauricio Barbosa ${ }^{4}$, \\ Kah-Hay Yuen ${ }^{2}$, Abu Bakar Abdul Majeed ${ }^{1, \infty}$ \\ ${ }^{1}$ Nanopharmacy Research Unit, Faculty of Pharmacy, Universiti Teknologi MARA, Shah Alam, Selangor, Malaysia; \\ E-Mail: abubakar@salam.vitm.edu.my; adrianapmak@yahoo.com \\ 2 School of Pharmaceutical Sciences, Universiti Sains Malaysia, Pinang, Malaysia \\ 3 Hovid Bhd, 121, Jalan Tunku Abdul Rahman, Ipoh, Perak, Malaysia \\ 4 Serviço de Tecnologia Farmacêutica, Faculdade de Farmácia da Universidade do Porto and CEQUIMED-UP, Centro de Química Medicinal \\ da Universidade do Porto, Porto, Portugal
}

\begin{abstract}
A sensitive and rapid routine LC method was validated for measuring cefotaxime incorporated in three different $\mathrm{pH}$-sensitive nanoparticles. The drug was chromatographed on a $\mathrm{Cl} 8$ reversed-phase column; the mobile phase used was $0.05 \mathrm{M}$ aqueous ammonium acetate, acetonitrile and tetrahydrofuran $(87: 11: 2, v / v)$ adjusted to $\mathrm{pH} 5.5$ with acetic acid. The flow rate was $1 \mathrm{~mL} \mathrm{~min}{ }^{-1}$ and cefotaxime was quantified at $254 \mathrm{~nm}$, with a sensitivity range of 0.005 AUFS. The validated method was specific, linear $\left(R^{2} \geq 0.999\right)$, precise and accurate in a concentration range of $0.2-50.0 \mu \mathrm{g} \mathrm{mL}^{-1}$. The method was rapid, selective and suitable for evaluation of cefotaxime in $\mathrm{pH}$-sensitive Eudragit nanoparticles.
\end{abstract}

\section{Keywords}

Column liquid chromatography

$\mathrm{pH}$-Sensitive nanoparticles

Cefotaxime

Eudragit

\section{Introduction}

Cefotaxime sodium is a water soluble semisynthetic third-generation cephalosporin (Fig. 1). It is a peptidomimetic drug which exists as zwitterionic compound at physio- logical $\mathrm{pH}$ and unable to permeate the gastrointestinal mucosa. Thus, it is not appreciably absorbed on peroral administration and consequently presents poor oral bioavailability, falling into the class III of the Biopharmaceutics Classification System [1].
Due to the cefotaxime sodium similarity in structure and biopharmaceutical profile with proteins and peptides it might be used as a model drug for characterizing the incorporation of peptidomimetics in nanocarriers. This is important since the majority of the newly developed therapeutic molecules are peptides or proteins $[2,3]$. Nanocarriers, such as $\mathrm{pH}$-sensitive nanoparticles, may constitute an alternative to overcome the difficulties related to poor permeability of peptidomimetic compounds and improve their oral bioavailability. This approach has been applied to different drugs [4-7].

$\mathrm{pH}-$ Sensitive nanoparticles are matrix-type disperse systems of nanometer size [8]. They can protect labile macromolecules from stomach acid and the first-pass metabolism in the gastrointestinal tract [9] and reduce side effects [10]. Moreover, due to their inherent $\mathrm{pH}$ sensitive property, the incorporated drug can be released at a specific $\mathrm{pH}$ within the gastrointestinal tract, as close as possible to its absorption window [7, 11]. Acrylic polymers such as Eudragit L100, Eudragit L100-55 and Eudragit S100 are co-polymers of poly(methacrylic acid and methacrylate), which can dissolve 


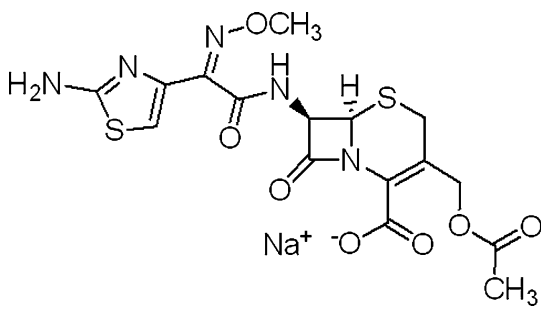

Fig. 1. Chemical structure of cefotaxime sodium

rapidly at specific $\mathrm{pH}$ values. Thereby, the release properties of nanoparticles formed by these polymers exhibit significant $\mathrm{pH}$-sensitivity [7].

In order to test the usefulness of Eudragit $\mathrm{pH}$-sensitive nanoparticles as potential carriers to improve cefotaxime sodium oral bioavailability, we are carrying out in vivo studies for formulations prepared with different types of Eudragit. To facilitate the pharmaceutical development of cefotaxime sodium-containing nanoparticle formulations an analytical method for the quantitation of drug and characterization of its in vitro release profile is needed to guarantee the reliability of the results $[12,13]$. Different methods for determination of cefotaxime sodium in simple solutions and plasma have been described [1, 14-22]. However, some important drawbacks, such as complex sample preparation and/or incomplete validation, were observed for the reported methods. As such, new methodologies have been developed to overcome these limitations when a plasma matrix is used [23-25]. The aim of the present work was to adapt this method for the quantitation of cefotaxime which was entrapped for the first time into $\mathrm{pH}$ sensitive nanoparticles and to validate it through the methodologies and parameters recommended by the International Conference on Harmonization [26, 27], which are similar to the ones established by the United States Pharmacopoeia 29 (USP 29) [28].

\section{Experimental}

\section{Chemicals and Reagents}

Cefotaxime sodium was obtained from Orchid Chemicals and Pharmaceuticals (Chennai, India). Eudragit L100,
Eudragit L100-55 and Eudragit S100 were purchased from Degussa (Singapore). Disodium hydrogen orthophosphate was obtained from Fisher Scientific (Singapore). Acetonitrile was acquired from LAB-SCAN (Bangkok, Thailand). Ammonium acetate, perchloric acid $(70 \%, w / w)$ and tetrahydrofuran were obtained from Merck (Darmstadt, Germany). Glacial acetic and hydrochloric acid were purchased from BDH (Poole, England). Sodium chloride was acquired from Fluka (Deisenhofen, Germany). Pepsin, pancreatin and monobasic potassium phosphate were purchased from Sigma (St. Louis, MO, USA). LC grade water was obtained by a MilliQ system (Millipore, Singapore). All solvents and chemicals used were of analytical or LC grade.

\section{Apparatus}

The experiments were performed on an Waters Breeze LC system (Waters, Milford, MA, USA), comprising a Waters 1525 Binary LC pump, a 717 Plus autosampler, a Rheodyne $7725 \mathrm{i}$ sample injector, a Symmetry C18 (5 $\mu$ m, $4.6 \times 250 \mathrm{~mm})$ column, fitted with a Universal Sentry Guard Holder packed with Nova-Pack cartridge, a 2487 dual wavelength absorbance detector and a computer with a Breeze software that controls the system and displays the results. The $\mathrm{pH}$ of the solutions was measured by a pH-meter from Mettler Toledo Seven Easy (Mettler Toledo, Shah Alam, Malaysia).

\section{Chromatographic Conditions}

The mobile phase was composed of a mixture of $0.05 \mathrm{M}$ aqueous ammonium acetate-acetonitrile-tetrahydrofuran $(87: 11: 2, v / v)$, adjusted to $\mathrm{pH} 5.5$ with glacial acetic acid. The mobile phase was filtered using a $0.45 \mu \mathrm{m}$ Teflon membrane filter (Millipore, Milford, MA, USA) and degassed by sonication prior to use. It was pumped through the system at a flow rate of $1.0 \mathrm{~mL} \mathrm{m^{-1 }}$ by isocratic elution. All the determinations were performed at ambient temperature. The detection wavelength was set at
$254 \mathrm{~nm}$ and the sensitivity adjusted to 0.005 absorbance units full scale (AUFS). The samples were quantified based on the peak height.

\section{Nanoparticle Preparation and Characterization}

$\mathrm{pH}$-Sensitive nanoparticles were prepared by a novel $\mathrm{pH}$-sensitive nanoprecipitation method, which is under optimization [11]. Briefly, a $0.7 \%$ polymeric solution (Eudragit L100, Eudragit L100-55 or Eudragit S100) was added with an amount of cefotaxime sodium to obtain a 1:1 $(w / w)$ polymer:drug ratio. Then, a precipitating solution (1 M acetic acid) was added under moderate stirring. Obtained nanodispersions were left at room temperature for established periods of time. Non-incorporated drug was separated by ultracentrifugation at $90,000 \times g$ for $4 \mathrm{~h}$ (Optima LE 80-K ultracentrifuge, Beckman Coulter, Fullerton, CA, USA). Pelleted nanoparticles were quickly frozen by immersion into liquid nitrogen and freeze-dried without heating for $24 \mathrm{~h}$ (Labconco Freeze Dry System, Kansas, MI, USA). Blank nanoparticles were prepared by the same method but omitting the addition of drug.

Size and zeta potential of nanoparticles were measured using a Zetasizer Nano ZS (Malvern instruments, Malvern, UK).

Calculation of the percentage of nanoparticle recovery, drug encapsulation efficiency and drug entrapment was performed using the following equations [29]:

$$
\begin{aligned}
& \text { Nanoparticle recovery }(\%) \\
& =\frac{\text { Mass of nanoparticle recovered }}{\text { Mass of polymeric material and drug used }} \\
& \quad \times 100
\end{aligned} \quad \begin{aligned}
& \text { Drug content }(\%) \\
& =\frac{\text { Mass of drug in nanoparticles }}{\text { Mass of nanoparticles recovered }} \times 100 \\
& \text { Drug entrapment }(\%) \\
& =\frac{\text { Mass of drug in nanoparticles }}{\text { Mass of drug used in the formulation }} \times 100
\end{aligned}
$$

\section{Preparation of Standard Solutions}

A cefotaxime sodium stock solution $\left(50 \mu \mathrm{g} \mathrm{mL}^{-1}\right.$ ) was freshly prepared by 
dissolving the drug in $0.04 \mathrm{M} \mathrm{NaH}$ $\mathrm{PO}_{4} \cdot 2 \mathrm{H}_{2} \mathrm{O}$ buffer solution ( $\mathrm{pH}$ 5.5). The standard solutions were obtained by serial dilutions of the stock solution with the same buffer to give different concentrations over the range of interest $\left(0.2-50 \mu \mathrm{g} \mathrm{mL}^{-1}\right)$. Upon preparation all solutions were covered with aluminum foil in order to protect them from light.

\section{Preparation of Sample Solutions for Cefotaxime Sodium Quantitation in Nanoparticles}

Sample solutions were prepared by dissolving $150 \mathrm{mg}$ of freeze-dried cefotaxime sodium loaded nanoparticles in $0.04 \mathrm{M} \mathrm{NaH} \mathrm{PO}_{4} \cdot 2 \mathrm{H}_{2} \mathrm{O}$ buffer solution ( $\mathrm{pH} 7$, adjusted with glacial acetic acid) under sonication. This $\mathrm{pH}$ was selected in order to achieve a complete dissolution of the used polymers, since the maximum $\mathrm{pH}$ thresholds are 5.5 for Eudragit L100-55, 6.0 for Eudragit L100 and 7.0 for Eudragit S100 [30]. A $250 \mu \mathrm{L}$ aliquot of the previous solution was further diluted to $25 \mathrm{~mL}$ with the same phosphate buffer but with a $\mathrm{pH}$ of 5.5 (adjusted with glacial acetic acid), which corresponds to the maximum cefotaxime sodium stability. Then, samples were subjected to LC analysis. All analyses were performed in quadriplicate.

\section{Statistical Analysis}

Analysis of variance (ANOVA) was used to validate statistically the differences among the entrapment values of cefotaxime sodium in nanoparticles. Analysis was performed using SPSS 12 (SPSS, Chicago, IL, USA).

\section{Method Validation}

The procedures and parameters adopted for the validation of the chromatographic method in this study are those described in the ICH guidelines [26, 27], which are similar to the ones established by the USP 29 [28]. The following parameters were determined: specificity,
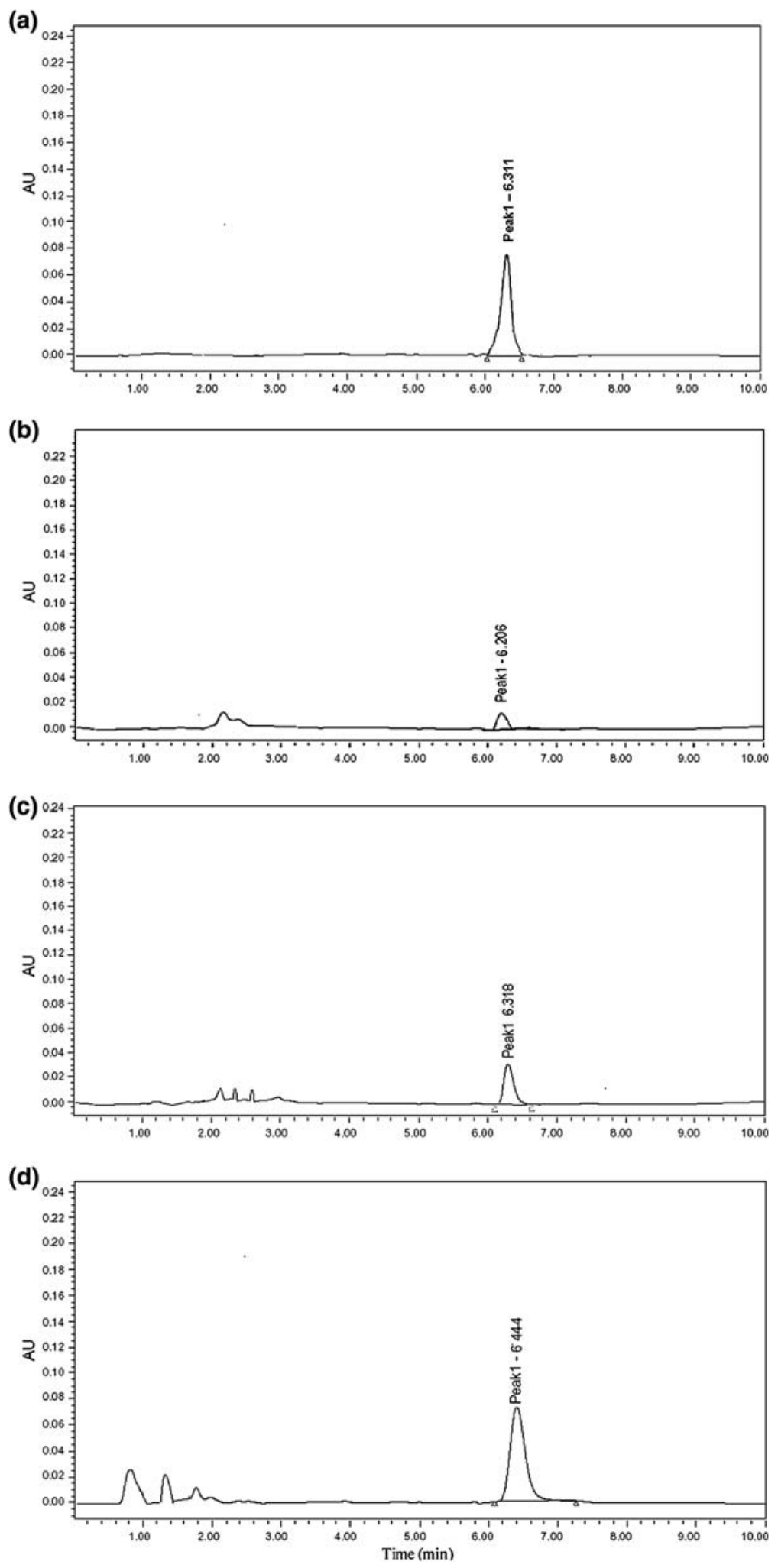

Fig. 2. Representative chromatograms obtained following injection of a cefotaxime standard solution $\left(3.13 \mu \mathrm{g} \mathrm{mL}^{-1}\right)$, b cefotaxime standard solution $\left(0.78 \mu \mathrm{g} \mathrm{mL} L^{-1}\right)$ spiked with Eudragit L100 nanoparticles, $\mathbf{c}$ cefotaxime standard solution $\left(1.56 \mu \mathrm{g} \mathrm{mL}^{-1}\right)$ spiked with Eudragit L10055 nanoparticles and $\mathbf{d}$ cefotaxime standard solution $\left(3.13 \mu \mathrm{g} \mathrm{mL}^{-1}\right)$ spiked with Eudragit $\mathrm{S} 100$ nanoparticles 
Table 1. Summary of standard curve results

\begin{tabular}{|lcl|}
\hline $\begin{array}{l}\text { Concentration } \\
\text { of cefotaxime } \\
\left(\mu \mathrm{g} \mathrm{mL}^{-1}\right)\end{array}$ & $\begin{array}{l}\text { Average } \\
\text { peak height } \\
(\mathrm{V})\end{array}$ & $\begin{array}{l}\mathrm{CV} \\
(\%)\end{array}$ \\
\hline 0.20 & 538 & 1.48 \\
0.39 & 1,102 & 1.91 \\
0.78 & 2,102 & 0.50 \\
1.56 & 3,868 & 1.35 \\
3.13 & 7,995 & 1.08 \\
6.25 & 15,937 & 0.91 \\
12.50 & 31,841 & 1.02 \\
25.00 & 63,947 & 0.49 \\
50.00 & 127,973 & 0.61 \\
\hline
\end{tabular}

$y$-Intercept $=0.63201 \pm 79.86$ and Slope $=$ $2,555.92 \pm 2.04$, with confidence limits $P=$ 0.05 ; correlation coefficient $(r)=0.99998$; coefficient of determination $\left(R^{2}\right)=0.99997$

range and linearity, precision, accuracy, DL, QL, robustness and system suitability test.

\section{Specificity}

$\mathrm{ICH}$ defines specificity as the ability to assess unequivocally the analyte in the presence of components that may be expected to be present, such as impurities, degradation products and matrix components. In practice, this can be performed by spiking the drug substance with appropriate levels of impurities/excipients and demonstrating that the assay results are unaffected by the presence of these potential interferences [26, 27]. In the present study, the specificity of the analytical method was determined by comparing the results from the analysis of cefotaxime standard solutions over the range of interest $\left(0.2-50 \mu \mathrm{g} \mathrm{mL}^{-1}\right)$ and the same standards spiked with blank nanoparticles prepared with each type of Eudragit.

\section{Linearity and Range}

The linearity of an analytical method is its ability to produce test results that are directly proportional to the concentration of analyte in the sample, within a given range [27]. In the present study, linear regression was performed by plotting average peak height $(y)$ versus the analyte concentration $(x)$ in the concentration range of $0.2-50 \mu \mathrm{g} \mathrm{mL}^{-1}$.
Calibration curves were constructed at nine concentration levels using the linear-squares regression procedure. The overall experiments were repeated six times on different days. The obtained peak height values were averaged at each concentration.

\section{Accuracy}

The accuracy of an analytical method expresses the closeness of agreement between the value that is accepted either as a conventional true value (or an accepted reference value) and the achieved experimental value [27]. Accuracy is normally calculated as the percentage of recovery by the assay of known spiked amounts of analyte into the sample. In the present study, to assess the accuracy of the proposed method, recovery experiments were carried out by spiking known amounts of cefotaxime sodium to blank nanoparticles (L100, L100-55 and S100) to achieve final theoretical concentrations of cefotaxime sodium between 0.2 and $50 \mu \mathrm{g} \mathrm{mL}^{-1}$. Experiments were done at nine concentration levels. For each level, drug content was determined in replicates $(n=6)$.

\section{Precision}

The precision of an analytical method is the degree of agreement among individual test results when the method is applied repeatedly to multiple samplings of a homogeneous sample [27]. It is normally expressed as the coefficient of variation in percentage $(\mathrm{CV})$ for a significant number of samples. Precision may be measured as repeatability, reproducibility and intermediate precision. Since reproducibility refers to the use of analytical procedure in different laboratories, for this specific case we have studied repeatability (intra-assay precision) and intermediate precision. To determine intra-assay precision six replicates of standard solutions (nine different concentrations) were analyzed by the same analyst within the same day. Intermediate precision of the assay was determined by analysis of the same standard solutions on six consecutive days by the same analyst.

\section{Detection Limit and Quantitation Limit}

The detection limit (DL) is defined as the lowest concentration of the analyte in a sample that can be detected by the method of analysis [27]. The quantitation limit (QL) is defined as the lowest concentration of the analyte in sample that can be determined with acceptable precision and accuracy under stated operational conditions for the method. In the present work, DL and QL were calculated according to the referred $\mathrm{ICH}$ guideline, from the slope and the standard deviation of the $y$-intercept of the mean of six calibration curves, as it follows:

$\mathrm{DL}=\frac{3.3 \sigma}{S}$

$\mathrm{QL}=\frac{10 \sigma}{S}$

where $\sigma$ is the standard deviation of $y$-intercepts of regression lines and $S$ is the slope of the calibration curves.

\section{Robustness}

The evaluation of robustness should be considered in order to ensure that the validity of the analytical procedure is maintained whenever used, even for small variations on analytical solutions $[26,27]$. In this study, robustness was evaluated as the percentage of recovery by the assay when deliberate variations of $\mathrm{pH}$ or media composition on cefotaxime solutions were performed. This approach can predict the method applicability to $\mathrm{pH}$ variations/media composition during sample handling and in vitro testing.

Recovery experiments were carried out by measuring cefotaxime sodium on standard solutions $\left(125 \mu \mathrm{g} \mathrm{mL}^{-1}\right)$ prepared at different $\mathrm{pH}$ values $(1.0 ; 4.0$; $4.3 ; 4.6 ; 5.0$ and 7.0 ) and on USP 29 simulated gastric and intestinal fluids. Experiments were done in replicates $(n=4)$. Buffer solution $\mathrm{pH} 1.0 \pm 0.1$ consisted in $0.1 \mathrm{M} \mathrm{HCl}$. All the other buffer solutions $(\mathrm{pH} \quad 4.0 \pm 0.1$, $4.3 \pm 0.1, \quad 4.6 \pm 0.1, \quad 5.0 \pm 0.1 \quad$ and $7.0 \pm 0.1)$ were composed by $0.05 \mathrm{M}$ $\mathrm{NaH}_{2} \mathrm{PO}_{4} \cdot 2 \mathrm{H}_{2} \mathrm{O}$ and the respective $\mathrm{pH}$ values were adjusted with glacial acetic acid. Upon preparation, the cefotaxime 
sodium standard solutions were incubated at $37{ }^{\circ} \mathrm{C}$ in a dissolution tester vessel (Vankel VK 7000 dissolution tester, Vankel, Cary, NC, USA) with the paddle speed rotating at $100 \mathrm{rpm}$. At pre-established times $1 \mathrm{~mL}$ samples were collected and replaced by fresh medium. Aliquots were further diluted with $9 \mathrm{~mL}$ of $0.5 \mathrm{M}$ ammonium acetate buffer solution and a mixture with $\mathrm{pH}$ of 5.5 was obtained. The amount of cefotaxime in the samples was immediately analyzed after collection by the proposed LC method.

\section{Results and Discussion}

\section{Specificity}

Figure $2 \mathrm{a}$ shows a representative chromatogram of a cefotaxime sodium standard solution $\left(3.13 \mu \mathrm{g} \mathrm{mL}^{-1}\right)$ with a retention time of 6.3 min. Figure $2 b-d$ show representative chromatograms obtained for cefotaxime sodium standard solutions of different concentrations $\left(0.78 ; 1.56\right.$ and $\left.3.13 \mu \mathrm{g} \mathrm{mL}^{-1}\right)$ spiked with a fixed amount of blank nanoparticles $(\leftrightarrow 0.375 \mathrm{mg}$ of nanoparticles $\mathrm{mL}^{-1}$ in the final solution) prepared with each one of the three Eudragit polymers (L100, L100-55 and $\mathrm{S} 100)$. The total running time for the samples was $10 \mathrm{~min}$. No peak from possible degradation products was observed in the chromatograms, as mentioned in other studies [31], showing the purity and stability of cefotaxime sodium in the studied conditions. The absence of any peak or interference at the elution point of cefotaxime rendered the method specific.

\section{Linearity and Range}

Regression statistics are summarized in Table 1. The assay was linear with a CV of $4.1 \%$ in the response factors (peak height divided by concentration) in the tested concentration range and coefficients of correlation $(r)$ and determination $\left(R^{2}\right)$ were found to be higher than 0.9999 , indicating a functional linear relationship (over $99.99 \%$ ) between the

Table 2. Recovery of cefotaxime from nanoparticle formulations prepared with different Eudragit types

\begin{tabular}{|c|c|c|c|c|c|c|}
\hline \multirow[t]{2}{*}{$\begin{array}{l}\text { Theoretical cefotaxime } \\
\text { concentration }\left(\mu \mathrm{g} \mathrm{mL}^{-1}\right)\end{array}$} & \multicolumn{2}{|c|}{$\begin{array}{l}\text { Eudragit L100 } \\
\text { nanoparticles }^{\mathrm{a}}\end{array}$} & \multicolumn{2}{|c|}{$\begin{array}{l}\text { Eudragit L100- } \\
55 \text { nanoparticles }\end{array}$} & \multicolumn{2}{|c|}{$\begin{array}{l}\text { Eudragit S100 } \\
\text { nanoparticles }^{\mathrm{a}}\end{array}$} \\
\hline & $\begin{array}{l}\text { Recovery } \\
(\%)\end{array}$ & $\begin{array}{l}\text { CV } \\
(\%)\end{array}$ & $\begin{array}{l}\text { Recovery } \\
(\%)\end{array}$ & $\begin{array}{l}\text { CV } \\
(\%)\end{array}$ & $\begin{array}{l}\text { Recovery } \\
(\%)\end{array}$ & $\begin{array}{l}\mathrm{CV} \\
(\%)\end{array}$ \\
\hline 0.20 & 98.3 & 1.1 & 100.7 & 2.7 & 99.0 & 2.4 \\
\hline 0.39 & 99.5 & 2.0 & 100.4 & 2.0 & 98.8 & 1.3 \\
\hline 0.78 & 101.0 & 2.7 & 100.3 & 1.5 & 101.9 & 1.8 \\
\hline 1.56 & 100.9 & 1.5 & 99.6 & 1.1 & 100.3 & 1.2 \\
\hline 3.13 & 99.4 & 1.0 & 99.5 & 1.0 & 102.3 & 2.5 \\
\hline 6.25 & 99.6 & 3.2 & 99.0 & 1.2 & 100.2 & 2.8 \\
\hline 12.5 & 101.3 & 1.7 & 98.2 & 1.7 & 99.8 & 1.0 \\
\hline 25.0 & 100.2 & 1.2 & 99.3 & 3.0 & 100.5 & 2.1 \\
\hline 50.0 & 100.1 & 3.0 & 99.4 & 3.2 & 99.1 & 1.5 \\
\hline $\begin{array}{l}\text { Overall mean recovery } \\
(\%) \text { and } \mathrm{CV}(\%)\end{array}$ & 100.0 & 1.9 & 99.6 & 1.9 & 100.2 & 1.8 \\
\hline
\end{tabular}

${ }^{\mathrm{a}} n=6$

Table 3. Results of precision of the chromatographic method

\begin{tabular}{|lll|}
\hline $\begin{array}{l}\text { Theoretical cefotaxime } \\
\text { concentration }\left(\mu \mathrm{g} \mathrm{m}^{-1}\right)\end{array}$ & $\begin{array}{l}\text { Mean experimental } \\
\text { concentration }\left(\mu \mathrm{gL}^{-1}\right)\end{array}$ & $\mathrm{CV}(\%)$ \\
\hline Repeatability (intra-assay precision) $^{\mathrm{a}}$ & & \\
0.20 & 0.199 & 1.0 \\
0.39 & 0.388 & 0.7 \\
0.78 & 0.788 & 1.5 \\
1.56 & 1.564 & 2.3 \\
3.13 & 3.135 & 1.9 \\
6.25 & 6.247 & 1.8 \\
12.5 & 12.473 & 1.2 \\
25.0 & 25.006 & 2.4 \\
50.0 & 49.965 & 2.1 \\
Intermediate precision & \\
0.20 & 0.199 & 1.7 \\
0.39 & 0.390 & 1.8 \\
0.78 & 0.782 & 1.8 \\
1.56 & 1.559 & 1.2 \\
3.13 & 3.133 & 0.7 \\
6.25 & 6.249 & 1.5 \\
12.5 & 12.488 & 2.4 \\
25.0 & 24.999 & 2.5 \\
50.0 & 49.969 & 1.0 \\
\hline
\end{tabular}

${ }^{\mathrm{a}} n=6$

concentration of cefotaxime sodium in buffer solutions and the peak height. Results demonstrate good linearity in the studied range, meeting the criteria proposed by Epshtein [32].

\section{Accuracy}

Table 2 summarizes the accuracy results, expressed as percent recovery and CV. Recovery values were within the ranges of $98.3-101.0 \% \quad(\mathrm{CV}=1.0-3.2), 98.2-$
$100.7 \% \quad(\mathrm{CV}=1.0-3.2) \quad$ and $98.8-$ $102.3 \% \quad(\mathrm{CV}=1.0-2.8)$ for Eudragit L100, Eudragit L100-55 and Eudragit S100 nanoparticles, respectively. Overall mean recovery values were $100.0 \%$ ( $n=54)$ for Eudragit L100 nanoparticles, 99.6\% $(n=54)$ for Eudragit L10055 nanoparticles and $100.2 \% \quad(n=54)$ for Eudragit S100 nanoparticles. Because the mean recovery results were within an acceptable $\pm 3 \%$ range (1.84$1.93 \%$ ), according to Segall et al. [33] the method was deemed accurate. 
Table 4. Intra-assay precision of the entire analytical method for quantitation of cefotaxime from nanoparticle formulations prepared with different Eudragit types

\begin{tabular}{|c|c|c|c|c|c|c|}
\hline \multirow{2}{*}{$\begin{array}{l}\text { Theoretical cefotaxime } \\
\text { concentration }\left(\mu \mathrm{gL}^{-1}\right)\end{array}$} & \multicolumn{2}{|c|}{ Eudragit L100 nanoparticles ${ }^{a}$} & \multicolumn{2}{|c|}{ Eudragit L100-55 nanoparticles ${ }^{\mathrm{a}}$} & \multicolumn{2}{|c|}{ Eudragit S100 nanoparticles ${ }^{\mathrm{a}}$} \\
\hline & $\begin{array}{l}\text { Mean experimental } \\
\text { concentration }\left(\mu \mathrm{g} \mathrm{mL}^{-1}\right)\end{array}$ & $\mathrm{CV}(\%)$ & $\begin{array}{l}\text { Mean experimental } \\
\text { concentration }\left(\mu \mathrm{g} \mathrm{mL} L^{-1}\right)\end{array}$ & $\mathrm{CV}(\%)$ & $\begin{array}{l}\text { Mean experimental } \\
\text { concentration }\left(\mu \mathrm{g} \mathrm{mL}^{-1}\right)\end{array}$ & $\mathrm{CV}(\%)$ \\
\hline 0.20 & 0.198 & 2.7 & 0.201 & 1.4 & 0.199 & 1.0 \\
\hline 0.39 & 0.393 & 1.9 & 0.389 & 1.4 & 0.385 & 1.6 \\
\hline 0.78 & 0.782 & 1.8 & 0.772 & 1.4 & 0.784 & 1.7 \\
\hline 1.56 & 1.553 & 1.2 & 1.563 & 0.9 & 1.558 & 2.2 \\
\hline 3.13 & 3.125 & 2.5 & 3.134 & 0.2 & 3.129 & 2.4 \\
\hline 6.25 & 6.254 & 2.8 & 6.244 & 0.1 & 6.249 & 1.8 \\
\hline 12.5 & 12.493 & 1.0 & 12.498 & 1.0 & 12.503 & 1.4 \\
\hline 25.0 & 24.996 & 0.7 & 25.003 & 0.8 & 24.999 & 1.7 \\
\hline 50.0 & 50.005 & 1.5 & 49.997 & 1.5 & 50.002 & 0.9 \\
\hline $\mathrm{CV}$ average $(\%)$ & & 1.8 & & 1.0 & & 1.6 \\
\hline
\end{tabular}

${ }^{\mathrm{a}} n=6$

Table 5. Intermediate precision of the entire analytical method for quantitation of cefotaxime from nanoparticle formulations prepared with different Eudragit types

\begin{tabular}{|c|c|c|c|c|c|c|}
\hline \multirow{2}{*}{$\begin{array}{l}\text { Theoretical cefotaxime } \\
\text { concentration }\left(\mu \mathrm{g} \mathrm{mL}^{-1}\right)\end{array}$} & \multicolumn{2}{|c|}{ Eudragit L100 nanoparticles ${ }^{\mathrm{a}}$} & \multicolumn{2}{|c|}{ Eudragit L100-55 nanoparticles ${ }^{\mathrm{a}}$} & \multicolumn{2}{|l|}{ Eudragit S100 nanoparticles ${ }^{\mathrm{a}}$} \\
\hline & $\begin{array}{l}\text { Mean experimental } \\
\text { concentration }\left(\mu \mathrm{g} \mathrm{mL}^{-1}\right)\end{array}$ & $\mathrm{CV}(\%)$ & $\begin{array}{l}\text { Mean experimental } \\
\text { concentration }\left(\mu \mathrm{g} \mathrm{mL}^{-1}\right)\end{array}$ & CV $(\%)$ & $\begin{array}{l}\text { Mean experimental } \\
\text { concentration }\left(\mu \mathrm{g} \mathrm{mL} L^{-1}\right)\end{array}$ & $\mathrm{CV}(\%)$ \\
\hline 0.20 & 0.198 & 1.6 & 0.201 & 1.1 & 0.193 & 2.4 \\
\hline 0.39 & 0.389 & 1.6 & 0.392 & 1.7 & 0.391 & 0.5 \\
\hline 0.78 & 0.788 & 1.0 & 0.782 & 1.8 & 0.786 & 0.8 \\
\hline 1.56 & 1.568 & 0.2 & 1.554 & 2.4 & 1.563 & 0.7 \\
\hline 3.13 & 3.119 & 1.6 & 3.128 & 2.5 & 3.129 & 1.0 \\
\hline 6.25 & 6.244 & 0.1 & 6.234 & 2.6 & 6.239 & 1.6 \\
\hline 12.5 & 12.399 & 0.6 & 12.293 & 0.5 & 12.463 & 1.7 \\
\hline 25.0 & 25.018 & 0.9 & 24.899 & 0.8 & 25.099 & 2.2 \\
\hline 50.0 & 50.030 & 0.8 & 49.975 & 0.7 & 50.045 & 1.6 \\
\hline $\mathrm{CV}$ average $(\%)$ & & 0.9 & & 1.6 & & 1.4 \\
\hline
\end{tabular}

${ }^{\mathrm{a}} n=6$

Table 6. Results of recovery and CV for cefotaxime from standard solutions $\left(125 \mu \mathrm{g} \mathrm{mL}{ }^{-1}\right)$ of different $\mathrm{pH}$

\begin{tabular}{|c|c|c|c|c|c|c|c|c|c|c|c|c|}
\hline \multirow[t]{2}{*}{ Time (h) } & \multicolumn{2}{|c|}{$\mathrm{pH}=1.0^{\mathrm{a}}$} & \multicolumn{2}{|l|}{$\mathrm{pH}=4.0^{\mathrm{a}}$} & \multicolumn{2}{|l|}{$\mathrm{pH}=4.3^{\mathrm{a}}$} & \multicolumn{2}{|l|}{$\mathrm{pH}=4.6^{\mathrm{a}}$} & \multicolumn{2}{|l|}{$\mathrm{pH}=5.0^{\mathrm{a}}$} & \multicolumn{2}{|l|}{$\mathrm{pH}=7.0^{\mathrm{a}}$} \\
\hline & $\begin{array}{l}\text { Mean } \\
\text { recovery } \\
(\%)\end{array}$ & $\begin{array}{l}\text { CV } \\
(\%)\end{array}$ & $\begin{array}{l}\text { Mean } \\
\text { Recovery } \\
(\%)\end{array}$ & $\begin{array}{l}\text { CV } \\
(\%)\end{array}$ & $\begin{array}{l}\text { Mean } \\
\text { Recovery } \\
(\%)\end{array}$ & $\begin{array}{l}\text { CV } \\
(\%)\end{array}$ & $\begin{array}{l}\text { Mean } \\
\text { Recovery } \\
(\%)\end{array}$ & $\begin{array}{l}\text { CV } \\
(\%)\end{array}$ & $\begin{array}{l}\text { Mean } \\
\text { Recovery } \\
(\%)\end{array}$ & $\begin{array}{l}\text { CV } \\
(\%)\end{array}$ & $\begin{array}{l}\text { Mean } \\
\text { Recovery } \\
(\%)\end{array}$ & $\begin{array}{l}\text { CV } \\
(\%)\end{array}$ \\
\hline 0.5 & 97.1 & 1.7 & 100.2 & 0.5 & 100.6 & 0.6 & 101.2 & 1.6 & 99.8 & 0.4 & 99.5 & 0.7 \\
\hline 1 & 94.5 & 2.4 & 99.6 & 0.7 & 99.6 & 0.7 & 100.5 & 1.5 & 99.4 & 0.5 & 99.0 & 0.8 \\
\hline 2 & 86.7 & 1.5 & 99.6 & 1.8 & 99.6 & 0.8 & 99.9 & 1.1 & 98.8 & 1.0 & 99.1 & 1.0 \\
\hline 4 & 75.0 & 0.6 & 98.3 & 0.9 & 98.3 & 1.4 & 98.4 & 0.9 & 97.8 & 0.5 & 96.8 & 1.2 \\
\hline 6 & 61.7 & 2.2 & 96.7 & 1.9 & 96.7 & 1.7 & 97.1 & 0.8 & 96.8 & 0.7 & 97.0 & 0.9 \\
\hline 8 & 41.6 & 2.1 & 96.3 & 2.2 & 96.3 & 1.5 & 96.8 & 1.1 & 96.4 & 0.6 & 96.9 & 1.3 \\
\hline 24 & - & & 95.9 & 2.4 & 95.9 & 2.1 & 95.2 & 2.0 & 95.8 & 0.5 & 96.3 & 1.5 \\
\hline
\end{tabular}

${ }^{\mathrm{a}} n=4$

\section{Precision}

Table 3 summarizes precision of the chromatographic method. Tables 4 and 5 summarize precision of the total ana- lytical method, both intra-day and intermediate precision, respectively. Obtained $\mathrm{CV}$ values varied from 0.5 to 1.9 for the chromatographic method and 1.0-1.8 for intra-assay precision and from 0.9 to 1.6 for intermediate precision for the total analytical method, indicating that the used LC methodology showed acceptable precision, in agreement with the criteria proposed by 
Shabir [34], for which the mean CV value should be lower than $2 \%$.

\section{Detection Limit and Quantitation Limit}

For the calculation of DL and QL the calibration equations for cefotaxime sodium were generated by using the mean values of the six independent calibration curves. The obtained DL and QL values were 0.045 and $0.135 \mu \mathrm{g} \mathrm{mL}^{-1}$, respectively (i.e., the method is sensitive enough to detect $0.045 \mu \mathrm{g} \mathrm{mL}^{-1}$ and quantitate $0.135 \mu \mathrm{g} \mathrm{mL}^{-1}$ of cefotaxime sodium in the studied conditions).

\section{Robustness}

Tables 6 and 7 summarize the robustness results, expressed as percent recovery and CV. As expected, for cefotaxime solutions prepared either at $\mathrm{pH} 1.0$ or on USP 29 simulated gastric fluid, low recovery values $(\approx 40 \%)$ were obtained at the end of $8 \mathrm{~h}$ of incubation. Fabre et al. [35] also reported a marked decrease of the cefotaxime concentration at $\mathrm{pH} 1.6$ with a $40 \%$ recovery after $8 \mathrm{~h}$, due to the hydrolysis of the drug. Moreover, high CV values were observed, revealing a low degree of reproducibility of the results obtained in referred conditions.

For standard solutions prepared either at $\mathrm{pH} 4 ; 4.3 ; 4.6 ; 5$ and 7 , during $24 \mathrm{~h}$ of incubation, or on simulated intestinal fluid (during $8 \mathrm{~h}$ ), high recovery and low $\mathrm{CV}$ values were obtained. Cefotaxime sodium standard solutions in the $\mathrm{pH}$ range 4-7 showed recovery values between 95.2 and $96.3 \%(\mathrm{CV}=0.5-2.4 \%)$ at the end of $24 \mathrm{~h}$.

On simulated intestinal medium at the end of $8 \mathrm{~h}, 90 \%$ of recovery $(\mathrm{CV}=2.0 \%)$ were obtained. These results indicate that, for the $\mathrm{pH}$ range 4-7, the analytical procedure is robust with respect to sample $\mathrm{pH}$. This $\mathrm{pH}$ range comprises the $\mathrm{pH}$ values at which cefotaxime is exposed during the production of nanoparticles and release studies in USP 29 simulated intestinal fluid $(\mathrm{pH} 6.8 \pm 0.1)$. Therefore, the analytical procedure allows its use for cefotaxime sodium quantitation either in

Table 7. Results of recovery and CV for cefotaxime from standard solutions $\left(125 \mu \mathrm{g} \mathrm{mL}^{-1}\right)$ prepared in USP 29 simulated gastric and intestinal fluids

\begin{tabular}{|llllll|}
\hline \multirow{2}{*}{ Time (h) } & \multicolumn{2}{l}{ Simulated gastric fluid $^{\mathrm{a}}$} & & \multicolumn{2}{l|}{ Simulated intestinal fluid $^{\mathrm{a}}$} \\
\cline { 2 - 3 } & Mean recovery (\%) & CV (\%) & & Mean recovery (\%) & CV (\%) \\
\hline 0.5 & 96.13 & 1.0 & & 100.13 & 0.9 \\
1 & 93.25 & 1.1 & & 99.43 & 1.2 \\
2 & 85.83 & 1.4 & & 98.58 & 1.6 \\
4 & 70.55 & 2.2 & & 94.75 & 1.4 \\
6 & 55.53 & 2.4 & & 91.43 & 2.1 \\
8 & 36.73 & 3.2 & & 90.00 & 2.0 \\
\hline
\end{tabular}

${ }^{\text {a }} n=4$

Table 8. Results of the system suitability test

\begin{tabular}{|lllll}
\hline Parameter & \multicolumn{4}{l|}{ Cefotaxime sodium } \\
\cline { 2 - 5 } & Minimum & Maximum & \multirow{2}{*}{ CV (\%) } & Status \\
\hline Retention time (min) & 6.309 & 6.399 & 0.55 & Passed \\
Peak height (V) & 137645 & 142199 & 1.25 & Passed \\
\hline
\end{tabular}

${ }^{\mathrm{a}} n=4$

nanoparticle dispersions or in the release studies from the nanoparticulate systems. Interestingly, cefotaxime recovery in simulated intestinal medium $(90.0 \%)$ was lower than that observed for the $\mathrm{pH} 7$ solution (96.3\%). This loss of drug may be attributed to cefotaxime metabolism by pancreatin present in simulated intestinal fluid, as previously described for vancomycin by Claudius and Neau [36].

The system suitability test was also carried out to evaluate the reproducibility of the system for the analysis to be performed, using six replicate injections of a cefotaxime sodium standard solution $\left(50 \mu \mathrm{g} \mathrm{mL}^{-1}\right)$ prepared in a $0.04 \mathrm{M}$ $\mathrm{NaH}_{2} \mathrm{PO}_{4} \cdot 2 \mathrm{H}_{2} \mathrm{O}$ buffer solution $(\mathrm{pH}$ 5.5). The results given in Table 8 show that the evaluated parameters are within the suitable range, as proposed by Dalmora et al. [37].

\section{Application of the LC Method for the Quantitation of Cefotaxime Sodium in Nanoparticles}

The analytical method was shown to be effective, fast and meeting all criteria for method validation and was applied to the quantitation of cefotaxime sodium which was incorporated for the first time in Eudragit pH-sensitive nanoparticles.
Figure $3 a-c$ show representative chromatograms of nanoparticles containing cefotaxime sodium prepared with different types of Eudragit (L100, L10050 and S100). None of the chromatograms showed any interfering peaks.

Table 9 shows the physicochemical characterization parameters of nanoparticles, such as the mean particle size, polydispersity index, zeta potential and drug entrapment. Nanoparticles presented a mean size of approximately $100 \mathrm{~nm}$ with a narrow size distribution and negative zeta potential. However, their negativity varied with the Eudragit type used, being more marked for S100 nanoparticles $(-26.9 \pm 1.7 \mathrm{mV})$ and less marked for L100 nanoparticles $(-12.3 \pm 0.5 \mathrm{mV})$. Drug entrapment values were low in all cases, ranging between 4.3 and $5.0 \%$, and their differences were not statistically significant $(P>0.05)$. Low entrapment efficiencies of cefotaxime sodium in Eudragit nanoparticles prepared by the current method are due to the high water solubility of the drug which migrates towards the external aqueous phase during the nanoparticle formation. This phenomenon is even more pronounced due to the small size of the nanoparticles and hence their large surface area, as they undergo drug loss into the aqueous phase during formation. A similar explanation was 
(a)

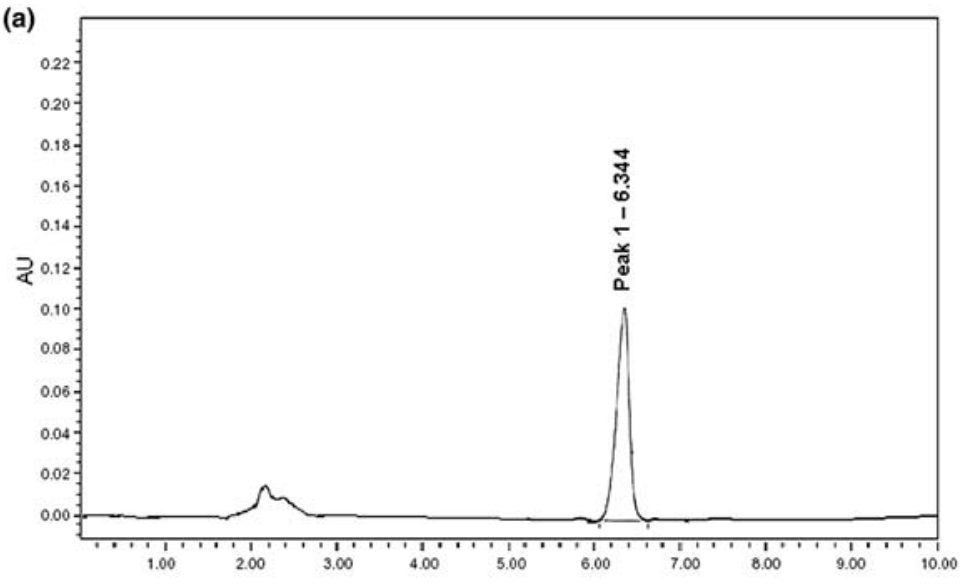

(b)
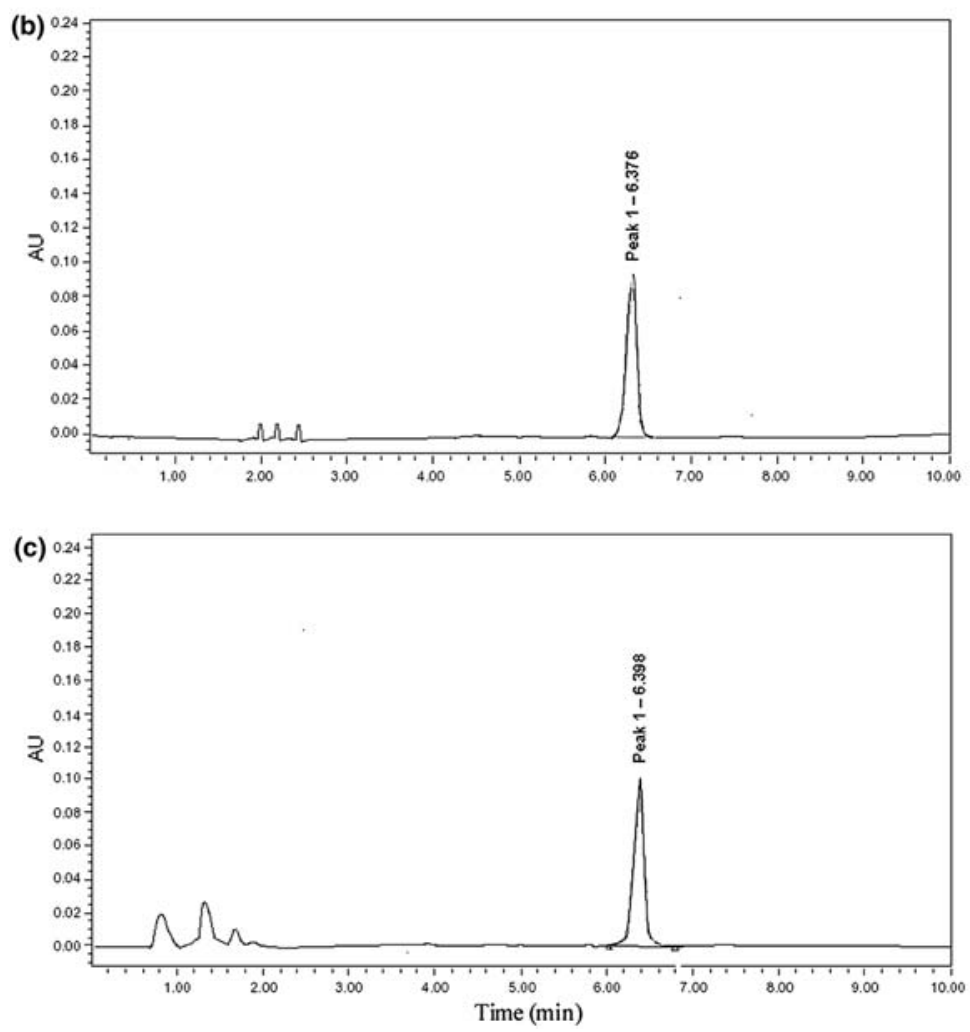

Fig. 3. Representative chromatograms of a cefotaxime loaded Eudragit L100 nanoparticles $\left(4.47 \mu \mathrm{g} \mathrm{mL}^{-1}\right)$, b cefotaxime loaded Eudragit L100-55 nanoparticles $\left(4.32 \mu \mathrm{g} \mathrm{mL}^{-1}\right)$ and $\mathbf{c}$ cefotaxime loaded Eudragit S100 nanoparticles $\left(4.03 \mu \mathrm{g} \mathrm{mL}^{-1}\right)$

Table 9. Physicochemical parameters of cefotaxime-loaded $\mathrm{pH}$-sensitive nanoparticles

\begin{tabular}{|llll|}
\hline $\begin{array}{l}\text { Physicochemical } \\
\text { parameters }\end{array}$ & $\begin{array}{l}\text { Eudragit L100 } \\
\text { nanoparticles }^{\mathrm{a}}\end{array}$ & $\begin{array}{l}\text { Eudragit L100-55 } \\
\text { nanoparticles }^{\mathrm{a}}\end{array}$ & $\begin{array}{l}\text { Eudragit S100 }^{\mathrm{a}} \\
\text { nanoparticles }^{\mathrm{a}}\end{array}$ \\
\hline $\begin{array}{l}\text { Mean size }(\mathrm{nm}) \\
\text { PDI }^{\mathrm{b}}\end{array}$ & $99.8 \pm 3.1$ & $99.5 \pm 2.2$ & $94.4 \pm 4.0$ \\
$\begin{array}{l}\text { Zeta potential }(\mathrm{mV}) \\
\text { Drug entrapment }(\%)\end{array}$ & $\begin{array}{l}0.177 \pm 0.005 \\
-12.3 \pm 0.5\end{array}$ & $\begin{array}{l}0.099 \pm 0.005 \\
-22.8 \pm 3.2\end{array}$ & $\begin{array}{l}-226 \pm 0.019 \\
-26.9 \pm 1.7\end{array}$ \\
\hline
\end{tabular}

${ }^{\text {a }}$ Values express the mean results $\pm \mathrm{SD}$ values of four different batches $(n=4)$

${ }^{\mathrm{b}}$ Varies from 0.0 corresponding to a perfect homogeneous dispersion to 1.0 corresponding to a complete heterogeneous dispersion proposed by Govender et al. [29] for the incorporation of a water soluble drug (procaine hydrochloride) in nanoparticles.

\section{Conclusions}

A simple isocratic reverse-phase LC method was validated for the determination of cefotaxime sodium in different Eudragit type nanoparticles, which was entrapped for the first time in these nanocarriers. The proposed method is simple, sensitive, reproducible and requires a small sample volume. Obtained results showed that it is specific, linear, accurate and precise within the established range, according to $\mathrm{ICH}$ guidelines and USP 29.

Validated method was successfully applied to the quantitation of cefotaxime sodium content in nanoparticle formulations, affording an important tool for the quality control of finished products. Eudragit based nanosystems are under optimization in order to improve drug entrapment and oral bioavailability studies are currently being undertaken in rats.

\section{References}

1. Sharma P, Chawla HP, Panchagnula R (2002) J Pharm Biomed Anal 27:39-50. doi:10.1016/S0731-7085(01)00506-4

2. Allemann E, Leroux J, Gurny R (1998) Adv Drug Del Rev 34:171-189. doi: 10.1016/S0169-409X(98)00039-8

3. Jung T, Kamm W, Breitenbach A, Kaiserling E, Xiao JX, Kissel T (2000) Eur J Pharm Biopharm 50:147-160. doi: 10.1016/S0939-6411(00)00084-9

4. Klipstein FA, Engert RF, Sherman WT (1983) Infect Immun 39:1000-1003. http:// iai.asm.org/cgi/content/abstract/39/2/1000

5. Morishita I, Morishita M, Takayama K, Machida Y, Nagai T (1993) Int J Pharm 91:29-37. doi:10.1016/0378-5173(93)90418-F

6. De Jaeghere F, Allémann E, Kubel F, Galli B, Cozens R, Doelker E, Gurny R (2000) J Control Release 68:291-298. doi: 10.1016/S0168-3659(00)00272-8

7. Dai J, Nagai T, Wang X, Zhang T, Meng M, Zhang Q (2004) Int J Pharm 280:229240. doi:10.1016/j.ijpharm.2004.05.006

8. Mangenheim B, Benita S (1991) STP Pharma Sci 1:221-241

9. Kreuter J, Munz K (1989) Int J Pharm 55:39-45. doi:10.1016/0378-5173(89)90274-3

10. McClean S, Prosser E, Meehan E, O'Malley D, Clarke N, Ramtoola Z, 
Brayden D (1998) Eur J Pharm Sci 6:153163. doi:10.1016/S0928-0987(97)10007-0

11. Pereira RE, Julianto TB, Yuen $\mathrm{KH}$, Majeed ABA (2008) EPharmaNexus 01:34-43

12. Teixeira M, Afonso CM, Pinto MM, Barbosa CM (2003) J Chromatogr Sci 41:371-376. http://www.j-chrom-sci.com/ abstracts/2003/August/371-barbosa.html

13. Teixeira M, Afonso CM, Pinto MM, Barbosa CM (2008) J Chromatogr Sci 46: 472-478. http://www.j-chrom-sci.com/ abstracts/2008/July/472-teixeira.html

14. Bergan T, Solberg R (1981) Chemotherapy 27:155-165. doi:10.1159/000237972

15. Lecaillon JB, Rouan MC, Soupart C, Fevre N, Judge F (1982) J Chromatogr Biomed Appl 228:257-267. doi:10.1016 S0378-4347(00)80438-7

16. Signs SA, File TM, Tan JS (1984) Antimicrob Agents Chemother 26:652-655 doi:10.1128/AAC

17. Scanes T, Hundt AF, Swart KJ, Hundt HK (2001) J Chromatogr B Biomed Sci Appl 750:171-176. doi:10.1016/S03784347(00)00417-5

18. Dell D, Chamberlain J, Coppin F (1981) J Chromatogr 226:431-440. doi:10.1016 S0378-4347(00)86077-6

19. Jehl F, Birckel P, Monteil H (1987) J Chromatogr 413:109-119. doi:10.1016/ 0378-4347(87)80218-9

20. Yost RL, Derendorf H (1985) J Chromatogr 341:131-138. doi:10.1016/S0378$4347(00) 84017-7$
21. Patel KB, Nicolau DP, Nightingale $\mathrm{CH}$, Quintiliani R (1996) Antimicrob Agents Chemother 40:2805-2808. http://aac.asm. org $/$ cgi/content/abstract $/ 40 / 12 / 2805$

22. Brisson AM, Fourtillan JB (1981) J Chromatogr 223:393-399. doi:10.1016/ S0378-4347(00)80112-7

23. Bertels RA, Semmekrot BA, Gerrits GP, Mouton JW (2008) Infection 36:415-420. doi:10.1007/s15010-008-7274-1

24. Ahsman MJ, Wildschut ED, Tibboel D, Mathot RA (2009) Antimicrob Agents Chemother 53:75-80. doi:10.1128/AAC. 00636-08

25. Seguin P, Verdier MC, Chanavaz C, Engrand C, Laviolle B, Donnio PY, Mallédant Y (2009) J Antimicrob Chemother 63:564-567. doi:10.1093/jac/dkn522

26. European Commission, Directorate General III-Industry Pharmaceuticals and Cosmetics (1998) Validation of analytical procedures: methodology. The rules governing medicinal products in European Union, 3A:107-117

27. European Commission. Directorate General III-Industry Pharmaceuticals and Cosmetics (1998) Validation of analytical procedures: definition and terminology. The rules governing medicinal products in European Union, 3A:119-125

28. United States Pharmacopeia 29/NF 24 (2005) Validation of compendial methods and test solutions. US Pharmacopeial Convention, Rockville, Maryland, USA, pp 3050-3052
29. Govender T, Riley T, Ehtezazi T, Garnett MC, Stolnik S, Illum L, Davis SS (2000) Int J Pharm 199:95-110. doi:10.1016/ S0378-5173(00)00375-6

30. Ceballos A, Cirri M, Maestrelli F, Corti G, Mura P (2005) Il Fármaco 60:913-918. doi:10.1016/j.farmac.2005.07.002

31. Zendelovska D, Stafilov T, Milosevski P (2003) Bull Chem Technol Macedonia 22:39-45

32. Epshtein N (2004) Pharm Chem J 38:212228. doi:10.1023/B:PHAC.0000038422. 27193.6c

33. Segall A, Hormaechea F, Vitale M, Perez V, Pizzorno MT (1999) J Pharm Biomed Anal 19:803-808. doi:10.1016/S0731-7085 (98)00120-4

34. Shabir GA (2004) Pharm Technol Eur 37-49. http://pharmtech.findpharma.com/ pharmtech/Analytical/HPLC-MethodDevelopment-and-Validation-for-Pharmac/ ArticleLong/Article/detail/89002

35. Fabre H, Eddine NH, Berge G (1984) J Pharm Sci 73:188-611. doi:10.1002/jps. 2600730508

36. Claudius JS, Neau SH, Kenny MT, Dulworth JK (1999) J Pharm Pharmacol 51: 1333-1337. http://www.ingentaconnect. com/content/rpsgb/jpp/1999/00000051/ 00000011/art00017

37. Dalmora SL, Sangoi Mda S, da Silva LM, Macedo RO, Barth T (2008) J Sep Sci 31:169-176. doi:10.1002/jssc.200700272 